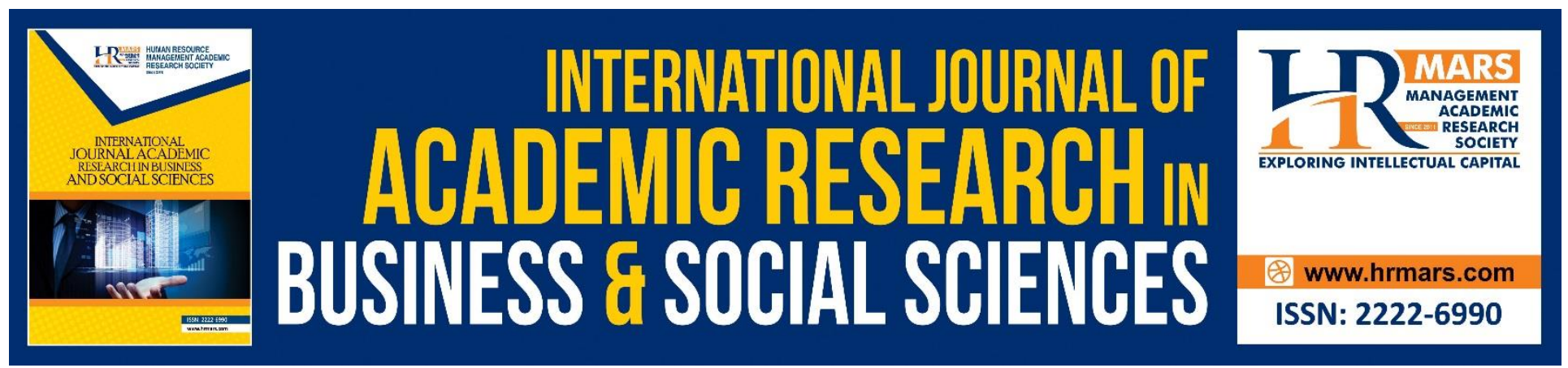

\title{
Parental Support and Coach Influence towards Career Decision Making Self-Efficacy among National Student Athletes in Malaysia
}

\section{Elaiyaraj Retnam, Azizan Asmuni, Siti Raba'ah Hamzah}

To Link this Article: http://dx.doi.org/10.6007/IJARBSS/v8-i9/4665

DOI: $\quad 10.6007 /$ IJARBSS/v8-i9/4665

Received: 09 August 2018, Revised: 25 August 2018, Accepted: 21 Sept 2018

Published Online: 15 October 2018

In-Text Citation: (Retnam, Asmuni, \& Hamzah, 2018)

To Cite this Article: Retnam, E., Asmuni, A., \& Hamzah, S. R. (2018). Parental Support and Coach Influence towards Career Decision Making Self-Efficacy among National Student Athletes in Malaysia. International Journal of Academic Research in Business and Social Sciences, 8(9), 917-934.

\section{Copyright: (C) 2018 The Author(s)}

Published by Human Resource Management Academic Research Society (www.hrmars.com)

This article is published under the Creative Commons Attribution (CC BY 4.0) license. Anyone may reproduce, distribute, translate and create derivative works of this article (for both commercial and non-commercial purposes), subject to full attribution to the original publication and authors. The full terms of this license may be seen at: $\underline{\text { http://creativecommons.org/licences/by/4.0/legalcode }}$

Vol. 8, No. 9, September 2018, Pg. 917 - 934

Full Terms \& Conditions of access and use can be found at http://hrmars.com/index.php/pages/detail/publication-ethics 


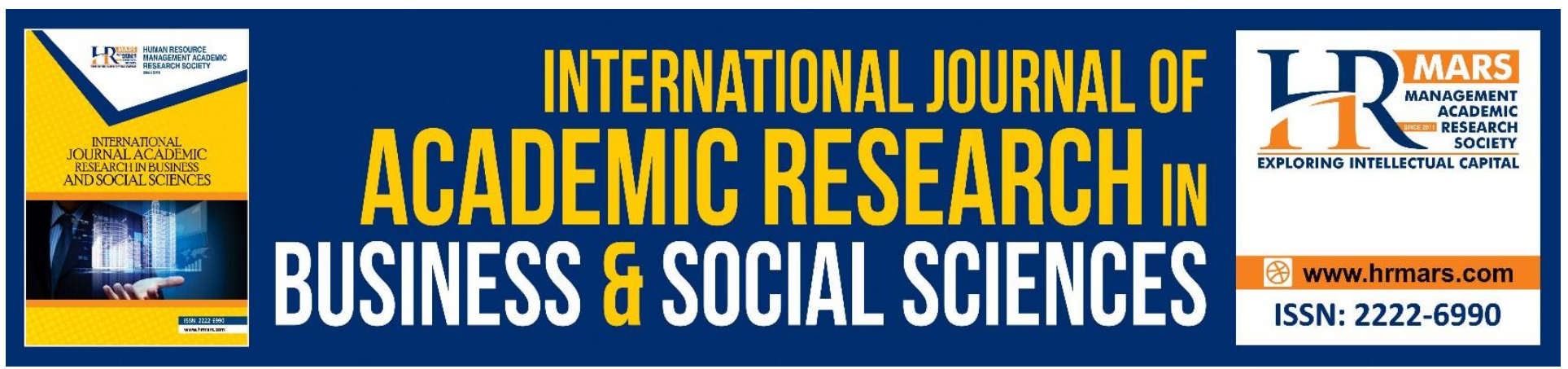

\title{
Parental Support and Coach Influence towards Career Decision Making Self-Efficacy among National Student Athletes in Malaysia
}

\author{
Elaiyaraj Retnam, Azizan Asmuni, Siti Raba'ah Hamzah \\ Department of Professional Development and Continuing Education, Faculty of Educational Studies, \\ Universiti Putra Malaysia, 43400 UPM, Serdang Selangor
}

\begin{abstract}
The purpose of this study is to understand the factors influencing career decision making self-efficacy among student athletes in National Sports Schools in Malaysia. This is a descriptive and correlative research study and based on theoretical framework of Social Cognitive Career Theory (Lent, Brown, \& Hackett, 1996). This study focused on the national athletes who are currently studying PreUniversity in the National Sports Schools. By using random sampling technique, 145 respondents among student athletes from two National Sports School were selected. Data were collected using the drop and pick-up method and self-administered questionnaires survey method. The analysis showed that most of the athletes demonstrated a moderate career decision making self-efficacy. Besides that, results from the correlation analysis indicate parental support and coach influence have significantly positive relationship with career decision making self-efficacy at 0.05 level of significant. While the test for regression analysis shows that both independent variables, explained $51.0 \%$ variance in student athletes career decision making self-efficacy. From the two predictors, parental support was the dominant predictor in student athletes career decision making self-efficacy with (Beta $=0.573$ ) followed by coach influence (Beta $=0.218$ ). These two predictors; parental support and coach influence are important and crucial in order to inculcate the career decision making selfefficacy of national student athletes. By emphasizing on the career development of national student athletes, athletes could easily boost their confidence and knowledge about career needs and have a secured future upon retiring as an athlete.
\end{abstract}

\section{Introduction}

Career decision-making is not a single decision; it begins in early childhood stage and continues throughout one's life. In elementary grades, children are taught self-understanding to help develop a healthy self-esteem. In upper elementary grades, children are introduced to jobs related to school subjects (McIntosh, 2000). As children move on to middle school, children are introduced to different 
INTERNATIONAL JOURNAL OF ACADEMIC RESEARCH IN BUSINESS AND SOCIAL SCIENCES Vol. 8, No. 9, Sept. 2018, E-ISSN: 2222-6990 @ 2018 HRMARS

careers by inviting employers in the community to visit the school or have students visit job sites within the community. Moving on, in high school, life career programs are available for students to participate in simulated situations about job choice, college, and adulthood (Mclntosh, 2000), also through education exhibitions. However, it is not the similar scenario for students who are studying in National Sports School Athlete. This student spent most of the routine in training and has very limited exposure to the career related information. Being a "National Sports School Athlete" is a foundational career that provides opportunities to develop leadership, communication, teamwork, motivation, and organizational skills. Unfortunately, many student athletes lag behind their nonpeers with regard to career readiness, failing to recognize how sport-related skills are valued in the world of work (Van-Raalte, Cornelius, Brewer \& Petitpas, 2017).

Moreover, it is difficult for student athletes to achieve a good dual career or to achieve sport-life balance. Jowett and Cramer (2009) mentioned that the sport environment often consumes the daily life of high-level athletes. Competitive student athletes might encounter overlap with class schedules, student-sport identity issues, and other issues related to physical fatigue, training requirements, and injuries (Parker, Perry, Hamm, Chipperfield, \& Hladkyj, 2016). Johnson, Wessel, and Pierce (2013) also found that competitive student athletes were at risk of dropping out of school due to athletic demands. Student athletes on a competitive level had to adapt to two distinct environments consisting of academics and sports (Parker, Perry, Hamm, Chipperfield \& Hladkyj, 2016). It was identified that most athletes recognized the dual career as being difficult and the academic transition to higher education might lead to changes in personal and academic responsibilities (MacNamara \& Collins, 2010). Although the interest in collegiate athletes has been increasing in sport science (Brown, Fletcher, Henry, Borrie, Emmett, Buzza, \& Wombwell, 2015), the information and knowledge on how to achieve a dual career or sport-life balance among student athletes is insufficient. Moreover, the relationship between well-being regarding the whole life and sport life needs to be examined (Lundqvist, 2011).

Career decision-making self-efficacy is defined as an individual's belief that he or she can successfully complete tasks necessary for making career decisions (Taylor \& Betz, 1983). It is an essential element that will assist any individual especially students to be able to choose the right major of study that will prepare and nurture them to face the working society. Difficulties in the career decision-making process leads to three major possible consequences: (1) the possibility for individuals to transfer the decision-making to others and refrain from deciding themselves, (2) failure in achieving the optimal career choice due to the delay in decision-making, and (3) temporary unemployment (Gati, Saka \& Krausz, 2001).

There are many factors that affect the decision-making skills of student athletes. Student athletes' future career decisions are influenced by their own attitudes and beliefs that are developed during socialization and in school as well as additional factors such as family members, members of their social group, adults with whom they interact at school, and mass media source. With that, one can see that the career decision-making process is difficult and involves planning because some student athletes do not recognize which decision they have to take regarding their future, they are uncertain 
INTERNATIONAL JOURNAL OF ACADEMIC RESEARCH IN BUSINESS AND SOCIAL SCIENCES Vol. 8, No. 9, Sept. 2018, E-ISSN: 2222-6990 @ 2018 HRMARS

about the career decision-making process, and many student athletes feel overwhelmed by the decisions that need to be made. A critical step in the career decision-making process is acquiring and structuring information. Therefore, "student athletes need to be given the opportunity to explore possible occupations, their values, strength and goals; their educational and career opportunities, and their role models and influences" (Julien, 1999). In present study, researcher seeks to know in depth about the support and opportunity gained by student athletes to explore their career opportunities.

Although student athletes have many opportunities to become better prepared to make career decisions, there are many barriers develop for some youth such as poverty, difficult home life, school problems, time constrain and negative community environments which limits their access for career information. These factors may interfere with what student athletes have learned in order to make a positive career choice. Career decisions are influenced by the resources available as well as family, friends, teachers and coaches (Mortimer, Zimmer-Gembeck, Holmes, \& Shanahan, 2002). It is important that the student athletes increase their awareness in variety of careers, so that student athletes are conscious about many career choices that are available in the market. Not only that, family and coaches are also needed to help the student athletes to develop self-worth and confidence in relation to careers and skills needed for specific careers. Family and coach may influence these student athletes by being role-models in the specific careers. Self-efficacy is an important factor in career decision-making. Career decision-making self-efficacy indicates that an individual can become successful in the career that is selected and commit to that career (Gushue, Scanlan, Pantzer \& Clarke, 2006). Betz and Voyten (1997) describe career decision outcome expectations as the belief that career exploratory behavior will lead to useful career development. According to Ramlee and Norhazizi (2009), in making a career decision, not all teenagers are systematic and rational. Many teenagers are still indecisive about their own stand after finishing secondary school and change their jobs for several times without having a lucid plan based insufficient information.

As a matter of fact, research studies pertaining career decision making self-efficacy of student athletes is limited in the context of Malaysia, hence the lack in understanding the needs of career decision making self-efficacy among student athlete undergraduates is vital as they are the future national assets. Therefore, this study aims to determine the relationship between parental support and coach influence towards career decision making self-efficacy among national student athletes in Malaysia.

\section{The Relationship between Coach Influence and Career Decision Making Self-Efficacy}

Many might question, how does a coach could be holding the authority on student athlete's academic development? To avoid coursework, classes during evening period and other academics activities, coaches and other sports management personals often hold great control over their student athletes to make sure academic activities does not interfere with scheduled training period (Bell, 2009; Huml, Hancock, Bergman, 2014; Kulics, Kornspan \& Kretovics, 2015). In terms of career development of student athletes, most of them believes their coach does not give emphasize on vocations that related to their degree but focus on athlete's career opportunities in sports (Cummins \& O'Boyle, 
2015). Instead of being a mentor to guide student athletes towards aligning course and major selection in regard to student athletes desired long term career goals and internship opportunities; the coaches have been shown to give priority on student athletes sports participation (Bell, 2009; Bimper, 2015). Student athlete's long-term job satisfaction and earning potential will be at stake and they might face negative consequences with misguided choice of courses and majors (Lawrence, Harrison, \& Stone, 2009).

To achieve a positive dual career, the athlete's entourage (e.g., coach, team staff, or mentor) plays an important role. For example, Alfermann, Geisler, and Okade (2013) identified that coaches contributed to Japanese athletes' feelings of satisfaction, unlike in the case of German athletes. Student athlete coaches have the important role to provide useful social support and enhance resilience to prevent burnout among athletes (Lu, Lee, Chang, Chou, Hsu, Lin, \& Gill, 2016). Thus, the coaching staffs are seen very important for the Japanese athletes. Moreover, to improve coaching, a mentoring system for both athletes and coaches was expected to be created (Lu et al., 2016). Therefore, a student athlete not only needs good coaches but also mentors in having positive dual careers especially in the case of Japanese athletes.

An athlete's entourage plays a key factor when providing support to the entire career of athletes. For example, mentors are one component of an athlete's entourage that is seen as crucial. Wang, Tomlinson, and Noe (2010) summarized previous research on mentoring as follows: "Mentoring refers to a relational process whereby a more experienced individual, usually more senior, contributes to the professional development of a protégé by providing three distinct types of functions." The three types of functions were psychosocial support, career-related support, and role modeling (Wang et al., 2010). A mentor refers to a person that greatly contributes to the growth of a person (Kodama \& Fukada, 2010). The action that a mentor, who helps, performs for the protégé, who is receiving the assistance or in another word, "mentee", is known as mentoring (Kodama \& Fukada, 2010). In this study, a protégé (mentee) refers to a student athlete and mentor refers to coach.

Ewing (1975) was one of the first researchers to investigate college athletes' career development. He compared the study habits, regularity between academic major and career interest, and academicrelated decision-making on a sample of 107 students and athletes. Ewing (1975) found that college athletes scored lower than students on acceptance of the education role. Also, college athletes had an external locus of control regarding academic decision-making, often allowing friends or coaches to make choices for them (Ewing, 1975). Sowa and Gressard (1983) analyzed the developmental task achievement of 75 college students and college athletes, using the Student Developmental Task and Lifestyle Inventory (Winston, Miller, \& Prince, 1982). College athletes scored significantly lower than students on measures of educational plans, career plans, and mature relationships with peers (Sowa \& Gressard, 1983). 
INTERNATIONAL JOURNAL OF ACADEMIC RESEARCH IN BUSINESS AND SOCIAL SCIENCES Vol. 8, No. 9, Sept. 2018, E-ISSN: 2222-6990 @ 2018 HRMARS

\section{Relationship between Parental Support and Career Decision Making Self-Efficacy}

Career decision making self-efficacy shows the self-confidence of a person who has the potential to perform task considered necessary to make future career related decisions (Taylor \& Betz, 1983). Career decision making represent a cognitive review or prediction of performance abilities in future which considered being a primary practice for personal agency through social cognitive selfregulation (Bandura, 1977). Indecisive choice in making a career is mostly students who lack in self confidence in their ability to perform task and behavior required for effective decision-making (Hargrove, Creagh \& Burgess, 2002; Taylor \& Betz, 1983). In shaping the process of career construction, career decision making self-efficacy is vital according to career construction theory, (Savickas, 2002). This is due to the fact that, career decision making self-efficacy helps a person to grow and implement their vocational self-concept in job-related roles. An individual is capable to better organize them self for future occupational prospects and to endure in future career pursuits, providing the person has greater career decision making as opposed to (Bandura, Barbaranelli, Caprara \& Pastorelli, 2001).

Past research suggests that, career decision making self-efficacy is developed through sources provided by parental support and it helps the students in handling difficulties in academics (AllimanBrissett, Turner, \& Skovholt, 2004; Metheny, McWhirter \& O'Neil, 2008). The theoretical perspective of the study can be studies more detail through social cognitive career theory (SCCT) which gives more support by offering an in-depth knowledge on how parental support is relevant to nurture career decision-making self-efficacy. As explained by SCCT, one's autonomy and perceived competence to face problems or obstacles could positively or negatively influenced by environmental and contextual factors or events which is essential in keeping one's inner confidence or autonomous forms of self-regulation.

The relationship between parental support and career decision making self-efficacy found to be positive which is also been demonstrated by a considerable number of researches. To support this, a study has reported that $29 \%$ to $43 \%$ of the total variance in vocational self-efficacy is accounted through perceived parental support (Turner \& Lapan, 2002). On another note, various minorities' students have reported that they obtain positive outcome on career development and self-efficacy through parental support (Ferry, Fouad, \& Smith, 2000; Fouad \& Bynner, 2008; Kenny, Blustein, Chaves, Grossman, \& Gallagher, 2003; Navarro, Flores, \& Worthington, 2007; Tang, Fouad, \& Smith, 1999). All the above discoveries can be generalized across the region of non-western contexts such as Malaysia (Garcia, Restubog, Toledano, Tolentino \& Rafferty, 2011; Restubog, Florentino \& Garcia, 2010).

A review of literature indicated that the Social Cognitive Career Theory (SCCT) seemed to be more suitable for examining the factors influencing career decision making self-efficacy among student athletes in National Sports School. The SCCT suggest career behavior is formed by person factor, contextual influence, and social cognitive factors. Empirical studies have demonstrated the relationships between SCCT variables. However, much of the research has been conducted in western 
societies and rather less has been done in Asian context. To fill this knowledge gap, the relationships between SCCT variables and career decision making self-efficacy among student athletes in National Sports School would be examined in present study. The SCCT was used as a framework to identify the variables significant to the career decision making self-efficacy among student athletes in National Sports School. The variables including career decision making self-efficacy, coach influence and parental support were selected with empirical or theoretical support from literature. The supports from parents are considered to be contextual factor which generates better perceived competence and self-determination to shape a person's career. Moreover, parental support helps a person to sense autonomy, freedom, exercise personal agencies and volition in career decision making, this is important for the development of career decision making self-efficacy.

Based on the theoretical approaches and previous findings discussed, it was hypothesized that there was relationship between parental support and coach influence on career decision making selfefficacy, among national athletes studying in National Sports School. Conceptual and theoretical framework was then established in this study in Figure 1.

$$
\text { Independent variables Dependent variables }
$$

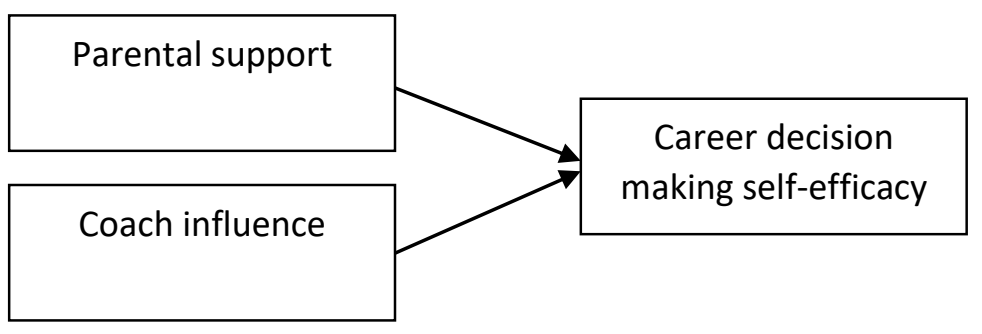

Figure 1: The framework of the study

\section{Methodology}

In this study, the independent variables were, parental support and coach influence, whereas career decision making self-efficacy was the dependent variable. Correlational research is widely used to clarify relationships and pattern of relationship among variables (Ary, Jacobs, \& Razavieh, 2002). It is mainly exploratory based, for an example, to identify the relationship existing between two or more variables. The research design for this study was applying the correlational study method which has been done to see the relationship between parental support and coach influence with level of career decision making self-efficacy.

Based on this, the research questions were structured to look for the relationships of these independent variables with the career decision making self-efficacy level. In order to answer to the research questions and their findings, a questionnaire was prepared and distributed to the targeted population which was first and second year Pre-University students in Bukit Jalil and Bandar Penawar Sports School. Due to the inability to assess the whole student athlete population, samples were 
INTERNATIONAL JOURNAL OF ACADEMIC RESEARCH IN BUSINESS AND SOCIAL SCIENCES

Vol. 8, No. 9, Sept. 2018, E-ISSN: 2222-6990 @ 2018 HRMARS

drawn for this study. Questionnaires containing the measurement instruments were used for the required data collections.

\section{Instruments for the study}

This study developed 25 items to measures Career Decision Making Self-Efficacy based on Career Decision Making Self Efficacy Scale - Short Form (Betz, Klein, \& Taylor, 1996) and 24 items to measures parental support which was adapted from Career-Related Parent Support Scale (Turner, Alliman-Brissett, Lapan, Udipi \& Ergun, 2003).

A total of 30 respondents were selected to participate in a pilot study. In order to ensure the validity and reliability of the instrument, a pre-testing was conducted before the actual research took place. The result of reliability coefficient of the three instruments (career decision making self-efficacy, parental support and coach influence) vary between 0.853 to 0.936 which is believed to be highly reliable and greater than the acceptable level of (0.7). The career decision making self-efficacy scale was adopted with 24 items $(\alpha=0.853)$, followed by parental support scale with 23 items $(\alpha=0.936)$ and coach influence scale with 14 items ( $\alpha=0.936)$. Data collected was analyzed by using the Statistical Package of Social Sciences (SPSS) version 23.0.

\section{Population and Sample}

The population in this study consists of 193 student athletes in their first and second year of PreUniversity studies in National Sports School. The total sample for this study by using Cochran's formula was found to be 128 samples. However, to avoid biasness and non-response the researcher has collected additional $10 \%$ from the required sample size.

In this study random sampling technique was used to determine the respondent for this study. Respondents were selected in a random order in both sports schools. Each sample elements identified is a representation of whole population of student athletes. The process begins by receiving consent from Principle of both schools to conduct research among student athletes studying in Year 1 and Year 2 of Pre-University. To begin with, the researcher has obtained the students list based on sequel numbers. Upon obtaining the sequel number for 193 students, random calculator was used to obtain a list of samples consist of 145 respondents. All students with selected number have been invited to participate in the questionnaire answering session. All students were assembled in an exam hall and the questionnaire was distributed. A briefing has been given by the researcher to make sure all students understand the items in questionnaire.

\section{Findings and Discussion}

In Table 1, there were $67.6 \%$ male and $32.4 \%$ female national student athletes who have successfully completed the questionnaire distributed. Respondents which are currently on year 1 semester 1 is (4.8\%), year 1 semester $2(46.2 \%)$, year 2 semester 2 is (5.5\%) and followed by year 2 semester 2 which is (43.4\%). There were only $0.7 \%$ student athletes, who had a cumulative grade point average below $1.99,60.7 \%$ student athletes had score between $2.00-2.99$, followed by $27.6 \%$ student athletes whom scored 3.00-3.49 and finally $11.0 \%$ student athletes who manage to score above 3.50 . The 
INTERNATIONAL JOURNAL OF ACADEMIC RESEARCH IN BUSINESS AND SOCIAL SCIENCES Vol. 8, No. 9, Sept. 2018, E-ISSN: 2222-6990 @ 2018 HRMARS

table also shows that the ratio of student athletes involved in team sports is slightly higher compared to student athletes participating in individual sports at $51 \%$ and $49 \%$ respectively. Besides that, $83.4 \%$ student athletes have made their decision on the future major course to be taken and the remaining $16.6 \%$ student athletes are still uncertain about their major course to be chosen.

Table 1: The demographic of the respondent $(n=145)$

\begin{tabular}{lccc}
\hline \multicolumn{1}{c}{ Profile } & Item & Frequency & Percentage \\
\hline Gender & Male & 98 & 67.6 \\
& Female & 47 & 32.4 \\
Year of study / & Year 1 Semester 1 & 7 & \\
semester & Year 1 Semester 2 & 67 & 4.8 \\
& Year 2 Semester 1 & 8 & 46.2 \\
& Year 2 Semester 2 & 63 & 5.5 \\
& & & 43.4 \\
Cumulative grade & $0-1.99$ & 1 & 0.7 \\
point average & $2.00-2.99$ & 88 & 60.7 \\
& $3.00-3.49$ & 40 & 27.6 \\
& $3.50-4.00$ & 16 & 11.0 \\
& & & \\
Type of sports & Individual & 71 & 49.0 \\
& Group & 74 & 51.0 \\
& & & \\
Decision on major & Yes & 121 & 83.4 \\
course to be taken & No & 24 & 16.6 \\
\hline
\end{tabular}

As mentioned in previous studies, student athletes have also voiced their satisfaction and need for the increased academic support. For example, Ridpath (2010) found certain subgroups (e.g. race, sport played, and gender) believed they need academic support to maintain their eligibility. In the present study, the ratio shows that, majority of the student are doing averagely on academics while performing at the highest level in sports arena. The role conflict between student and athlete led some of the college athletes into self-limiting academic behavior. Time constraints from practice, training, travel, and athletic contests were important factors in their decision process academically. Class selection, major selection, and academic progress were often only addressed after athletes were given priority. The short-term adjustment of an easier major or lighter class schedule sometimes put the athlete in a major track that they were not interested in or delayed their academic progress because of prerequisite requirements. These were similar challenges reported earlier in the literature (Blann, 1985; Adler \& Adler, 1991). The outcome of this self-limiting behavior on career development was more of a longer term, indirect effect. By the time the athletes began to make serious career plans or goals, they realized that the major they were involved in would not help them reach their 
INTERNATIONAL JOURNAL OF ACADEMIC RESEARCH IN BUSINESS AND SOCIAL SCIENCES Vol. 8, No. 9, Sept. 2018, E-ISSN: 2222-6990 @ 2018 HRMARS

goals. Similar delayed career planning was found in qualitative interviews with college athletes in Canada, (Lally \& Kerr, 2005).

Relationship between Parental Support and Coach Influence towards Career Decision Making SelfEfficacy among National Students Athletes in Malaysia

As shown in Table 2, parental support and career decision making self-efficacy among national student athletes in Malaysia found to be having the strongest relationship. $(r=.439 ; n=145$; sig- $p<$ .01). The correlation coefficient of .439 indicates a moderate positive relationship, which indicates that, when parental support increases, career decision making self-efficacy among national student athletes in Malaysia will increase. This proves that parental support has a significant positive relationship $(p<.01)$ with career decision making self-efficacy. Student athletes who receives moderate parental support will have moderate career decision making self-efficacy while student athletes with high parental support will have high level of career decision making self-efficacy. Since sig-p value is less than $\alpha$, hypothesis of the study was accepted and failed to reject it. This result also support with the theoritical integration between Career Construct Theory and Cognitive Evaluation Theory. Both theory explains that, the supports from parents are considered to be contextual factor which generates better perceived competence and self-determination to shape a person's career. Moreover, parental support helps a person to sense autonomy, freedom, exercise personal agencies and volition in career decision making, this is important for the improvement of career decision making self-efficacy.

This study in line with the previous studies conducted by (Chen, Shih, \& Yeh, 2011; Ibrahim, Isa \& Shahbudin, 2016), corellation between parental support and career decision making self-efficacy has been shown through various studies. For instance, it has been reported previously that perceived parental support estimated for $29 \%$ to $43 \%$ of the total variance in vocational self-efficacy (Turner and Lapan, 2002).

Meanwhile for coach influence, linear relationship was also found to exist between the variable and career decision making self-efficacy among national student athletes in Malaysia $(r=.365 ; n=145$; sig-p <.01). This indicates that, when score for coach influence increases, score for career decision making self-efficacy will also increase. The outcome highlights that coach influence also has a significant positive relationship $(p<.01)$ with the career decision making self-efficacy. Since sig- $p$ value is less than $\alpha$, hypothesis was accepted and failed to reject it. These is well evident with the support from Alfermann, Geisler, and Okade (2013) who identified that coaches contributed to Japanese athletes' feelings of satisfaction, unlike in the case of German athletes. Student athlete coaches have the important role to provide useful social support and enhance resilience to prevent burnout among athletes (Lu, Lee, Chang, Chou, Hsu, Lin, \& Gill, 2016). Thus, the coaching staffs are seen very important for the Japanese athletes. Moreover, to improve coaching, a mentoring system for both athletes and coaches was expected to be created (Lu, Lee, Chang, Chou, Hsu, Lin, \& Gill, 2016). Therefore, a student athlete not only needs good coaches but also mentors in having positive dual careers especially in the case of Japanese athletes.To achieve a positive dual career, the athlete's entourage (e.g., coach, team staff, or mentor) plays an important role. 
INTERNATIONAL JOURNAL OF ACADEMIC RESEARCH IN BUSINESS AND SOCIAL SCIENCES

Vol. 8, No. 9, Sept. 2018, E-ISSN: 2222-6990 @ 2018 HRMARS

The significant value for both parental support and coach influence are lower than < alpha (.01). Based on that, we may conclude that there was a significant relationship; between parental support and coach influence towards career decision making self-efficacy among national student athletes in Malaysia. While the student athletes are busy with their routine sports world, they still need support from parents and guidance from coaches to suceed in career.

Table 2: Bivariate correlations among variables, parental support and coach influence with career decision making self-eficacy $(n=145)$

\begin{tabular}{lccc}
\hline \multicolumn{1}{c}{ Variables } & CDMSE & PS & CI \\
\hline $\begin{array}{l}\text { Career decision making } \\
\text { self-eficacy (CDMSE) } \\
\text { Parental support (PS) }\end{array}$ & - & & \\
Coach influence (CI) & $.439^{* *}$ & - & \\
Mean & $.365^{* *}$ & $.479 * *$ & - \\
SD & 3.53 & 3.86 & 3.57 \\
\end{tabular}

\section{Conclusion}

On the whole, this study indicates that career decision making self-efficacy is an important factor which determines the future career undertaking of a Malaysian National student athletes. Moreover, this study proves that the career decision making self-efficacy of student athletes are influenced many factors and contextual factor are considered to be one of the most extensively researched. Generally, this study has provided important informations regarding the influence of coach and parental support towards career decision making self-efficacy among Malaysian National student athletes. It could be concluded that:

1. Majority of Malaysian National student athletes has reported a high level of support from parents. On the other side, Malaysian national student athletes has indicated that the influnce obtained from coaches towards career development found to be at moderate level and their career decision making sef-efficacy is also reported to be at moderate level. This indicates that, parents considered to be more supportive towards career development of student atheltes as coached are giving more emphasise on the sport development of a student athletes. Career decision making selfefficacy of Malaysian National student atheltes are still at moderate level, several other efforts need to be exercised such as assessing influence from various sources such as educational instituitions, families and peers; understand how student athletes prefer to enhance career decision making skills especially in terms of using digital media or social media; and to understand other commitments of student atheltes rather then academics and sports. 
2. The ability of parental support played an important role in cultivate career decision making self-efficacy among National student athletes. Student athletes has indicated that the level of parental support at the highest level and the relationship between parental support and career decision making self-efficacy is found to have a positive and moderate relationship. On the other hand, the influence of coach on career decision making self-efficacy among National student athletes also played an essential role though this study as it shows the lower strenght relationship compared to parental support. However, this study indicate there is relationship between coach influence and career decision making self-efficacy among National student athletes. This is in line with that evidence from past research as contextual support are found to be among the main factor that contributes towards career decision making self-efficacy. Moreover, the result of this study give impression that the Malaysian National student atheltes are not independent in career decision making and they need contextual support to increase the self-efficacy when it comes to career decision making. Besides that, it is important for the student atheltes to spend quality time with their parents and coaches as both are signifivcantly contributing towarsd career decision making self-efficacy as this will enhance their ability and knowledge upon retiring from sports arena and transition to future career undertaking.

3. Finally, among parental support and coach influnce, parental support make the strongest unique contribution to explaining the career decision making self-efficacy of Malaysian National student athletes and this is followed by the contribution from coach influnce. Student athletes career decision making self-efficacy is contributed by parental support as their are the most nearest individual to student atheltes and has much concern on the career development of the student atheltes. Thought the result of this study as well, parents are considered to be the most realiable source of career-related modelling, emotional support, verbal encouragement and instrumental support.

As a conclusion, the study on parental support and coach influence are consistent with previous study that describe the importance of the factor influencing career decision making self-efficacy among National student athletes. Therefore, these variables proven to be important in this study concerning career decision making self-efficacy among National student athletes. There is a significant need to give more empahsise on the career decision making self-efficacy among students in Malaysia as this will eradicate the unepmloyment rate and increase job satisfaction of an individual in future.

\section{Implication}

This study has several practical implications. Firstly, this study attempted to investigate how parental support contributes towards career decision making self-efficacy among National student athletes. Previous theory and research on career decision making self-efficacy supported the outcome of this research. For instance, it has been correspondingly proposed that the key factor for an individual to competently engage in their own career plan, compromising their academic obstacles is the parental guidance (Alliman-Brissett, Turner, \& Skovholt, 2004; Metheny et al., 2008).

The results of this study show that as the parental support and coach influence increase for student athletes so do their career decision-making self-efficacy. These results should encourage Ministry of Education and Ministry of Youth and Sports to design a framework which will enable the institutions 
under the ministries to develop programs which will enable students to develop their career decisionmaking skills as overall.

Besides that, there are several aspects that could potentially be used by practitioners (psychologist) to assist parents and coaches to enable them to support athletes to realise their potential career decision making self-efficacy for their future. This will enable the student athletes to have a broader knowledge on potential careers available for them.

Since these student athletes tend to differ from other students who are not in National sports schools, it is important to provide them with the information and support that will help to counteract inaccurate beliefs and that will serve to provide them with the knowledge that they may not be able to get from their parents or coaches. In addition, counselors can provide programs for all three parties which are parents, coaches and students that can help to fill the gap in knowledge by assisting them in the search process, the decision making process, college applications, financial aid, and preparing for future career undertaking. Small group guidance and counseling can be an effective and efficient way of providing services to a group of first generation student athletes, who can then continue to provide support to each other throughout the process and after they

Finally, youth organizations can develop career programs that fit in to their current programs and project clubs to reach more students who are lacking with career information. All these mentioned above will help in enhancing education system as a whole and create competitive youth in ensuring that Malaysia emerges as among the top 20 nations which is in line with the government's aspiration towards having a quality and innovative economic development by 2050 .

\section{References}

Adler, P. A., \& Adler, P. (1991). Backboards and blackboards: College athletes and role engulfment. New York: Columbia University Press.

Alfermann, D., Geisler, G., \& Okade, Y. (2013). Goal orientation, evaluative fear, and perceived coach behavior among competitive youth swimmers in Germany and Japan. Psychology of Sport and Exercise, 14, 307-315. doi:10.1016/j.psychsport.2012.11.005

Alliman-Brissett, A. E., Turner, S. L., \& Skovholt, T. M. (2004). Parent support and African American adolescents' career self-efficacy. Professional School Counseling, 7(3), 124-132.

Ary, D., Jacobs, L. C. \& Razavieh, A. (2002). Introduction to research in Education (6th ed.). United States of America, US: Wadsworth Group.

Bandura, A., Barbaranelli, G. V., Caprara, C., \& Pastorelli, C. (2001). Self-efficacy beliefs as shapers of children's aspirations and career trajectories. Child Dev., 72, 187-206. doi.org/10.1111/14678624.00273

Bandura, A. (1977). Self-efficacy: Toward a unifying theory of behavioral change. Psychological Review, 84, 191-215. doi:10.1037/0033-295X.84.2.191 
INTERNATIONAL JOURNAL OF ACADEMIC RESEARCH IN BUSINESS AND SOCIAL SCIENCES

Vol. 8, No. 9, Sept. 2018, E-ISSN: 2222-6990 (C) 2018 HRMARS

Bimper, A.Y. (2015). Lifting the veil: Exploring colorblind racism in Black student athlete experiences. Journal of Sport and Social Issues, 39, 225-243. doi:10.1177/ 0193723513520013

Bell, L. F. (2009). Examining academic role-set influence on the student-athlete experience (Special Issue). Journal of Issues in Intercollegiate Athletics, 2, 19-41.

Brown, D. J., Fletcher, D., Henry, I., Borrie, A., Emmett, J., Buzza, A., \& Wombwell, S. (2015). A British university case study of the transitional experiences of student athletes. Psychology of Sport and Exercise, 21, 78-90. doi:10.1016/j.psychsport.2015.04.002

Betz, N. E., \& Voyten, K. K. (1997). Efficacy and outcome expectations influence career exploration and decidedness. Career Development Quarterly, 46, 179-189. doi:10.1002/j.21610045.1997.tb01004.x

Betz, N. E., Klein, K., \& Taylor, K. (1996). Evaluation of a short form of the Career Decision Self-Efficacy Scale. Journal of Career Assessment, 4, 47-57. doi:10.1177/106907279600400103

Blann, F. (1985). Intercollegiate athletic competition and students' educational and career plans. Journal of College Student Personnel, 26, 115-118.

Cummins, P., \& O'Boyle, I. (2015). Psychosocial factors involved in transitions from college to post college careers for male NCAA Division-I basketball players. Journal of Career Development, 42, 33-47. doi:10.1177/0894845314532713

Chen, C. J., Shih, H. A., \& Yeh, Y. C. (2011). Individual initiative, skill variety, and creativity: The moderating role of knowledge specificity and creative resources. International Journal of Human Resource Management, 22, 3447-3461. doi:10.1080/09585192.2011.599940

Ewing, L. E. (1975). Career development of college athletes: Implications for counseling activities. Research Abstracts, 36, 7204.

Ferry, T. R., Fouad, N. A., \& Smith, P. L. (2000). The role of family context in a social cognitive model for career-related choice behavior: A Maths and Science perspective. Journal of Vocational Behavior, 57, 348-364. doi:10.1006/jvbe.1999.1743

Fouad, N. A., \& Bynner, J. (2008). Work transitions. Am. Psychol., 63, 241-251.

Gati, I., Saka, N. and Krausz, M., (2001). "Should I use a computer-assisted career guidance system?" It depends on where your career decision making difficulties lie. British Journal of Guidance \& Counselling, 29(3), 301-321. doi:10.1080/03069880124945

Garcia, P. R. J. M., Restubog, S. L. D., Toledano, L. S., Tolentino, L. R., \& Rafferty, A. E. (2011). 
INTERNATIONAL JOURNAL OF ACADEMIC RESEARCH IN BUSINESS AND SOCIAL SCIENCES Vol. 8, No. 9, Sept. 2018, E-ISSN: 2222-6990 @ 2018 HRMARS

Differential moderating effects of student-and parent-rated support in the relationship between learning goal orientation and career decision-making self-efficacy. Journal of Career Assessment, 20, 2-33. doi:10.1177/1069072711417162

Gushue, G. V., Scanlan, K. R., Pantzer, K. M., \& Clarke, C. P. (2006). The relationship of career decisionmaking self-efficacy, vocational identity, and career exploration behavior in African American high school students. Journal of Career Development, 33, 19-29. doi:10.1177/0894845305283004

Hargrove, B. K., Creagh, M. G., \& Burgess, B. L. (2002). Family interaction patterns as predictors of vocational identity and career decision-making self-efficacy. Journal of Vocational Behaviour, 61, 185-201. doi:10.1006/jvbe.2001.1848

Huml, M.R., Hancock, M.G., \& Bergman, M.J. (2014). Additional support or extravagant cost? Student athletes' perceptions on athletic academic centers. Journal of Issues in Intercollegiate Athletics, 7, 410-430.

Ibrahim, H., Isa, A., \& Shahbudin, A. (2016). Organizational support and creativity: The role of developmental experiences as a moderator. Procedia Economics and Finance, 35, 509-514.

Julien, H. E. (1999). Barriers to adolescents' information seeking for career decision making. Journal of the American Society for Information Science, 50(1), 38-48. doi:0002-8231/99/010038-11

Johnson, J. E., Wessel, R. D., \& Pierce, D. A. (2013). Exploring the influence of select demographic, academic, and athletic variables on the retention of student athletes. Journal of College Student Retention: Research, Theory and Practice, 15, 135-155. doi:10.2190/CS.15.2.a

Jowett, S. \& Cramer, D. (2009) The role of romantic relationships in athletes' performance and wellbeing. Journal of Clinical Sport Psychology, 3, 58-72. doi:10.1123/jcsp.3.1.58

Kenny, M. E., Blustein, D. L., Chaves, A., Grossman, J. M., \& Gallagher, L. A. (2003). The role of perceived barriers and relational support in the educational and vocational lives of urban high school students. J. Couns. Psychol., 50, 142-155. doi:10.1037/0022-0167.50.2.142

Kulics, J.M., Kornspan, A.S., \& Kretovics, M. (2015). An analysis of the academic behaviors and beliefs of Division I student athletes: The impact of the increased percentage toward degree requirements. College Student Journal, 49, 1-12.

Kodama, M., \& Fukada, H. (2010). The effect of mentoring on the working intentions of regular female employees rearing children: Considering work-family conflict and vocational identity as mediators. Japanese Journal of Social Psychology, 26, 1-12. 
INTERNATIONAL JOURNAL OF ACADEMIC RESEARCH IN BUSINESS AND SOCIAL SCIENCES

Vol. 8, No. 9, Sept. 2018, E-ISSN: 2222-6990 (C) 2018 HRMARS

Lally, P. S. \& Kerr, G. A. (2005). The career planning, athletic identity and student role identity of intercollegiate student athletes. Research Quarterly for Exercise \& Sport, 76(3), 275-285. doi:10.1080/02701367.2005.10599299

Lawrence, S.M., Harrison, C.K., \& Stone, J. (2009). A day in the life of a male college athlete: A public perception and qualitative campus investigation. Journal of Sport Management, 23, 591-614. doi:10.1123/jsm.23.5.591

Lent, R.W., Brown, S.D., \& Hackett, G. (1996). Career development from a social cognitive perspective. In D. Brown, L. Brooks, \& Associates (Eds.), Career choice and development (pp. 373-421). San Francisco: Jossey-Bass.

Lu, F. J. H., Lee, W. P., Chang, Y. K., Chou, C. C., H., Hsu, Y. W., Lin, J. H., \& Gill, D. L. (2016). Interaction of athletes' resilience and coaches' social support on the stress burnout relationship: A conjunctive moderation perspective. Psychology of Sport \& Exercise, 22, 202-209. doi:10.1016/j.psychsport.2015.08.005

Lundqvist, C. (2011). Well-being in competitive sports-The feel-good factor? A review of] conceptual considerations of well-being. International Review of Sport and Exercise Psychology, 4, 109127. doi: 10.1080/1750984x.2011.584067

Mclntosh, P. I., (2000). Life career development: implications for school counsellors. Education, 120, 621-628.

MacNamara, A., \& Collins, D. (2010). The role of psychological characteristics in managing the transition to university. Psychology of Sport and Exercise, 11, 353-362. doi:10.1016/j.psychsport.2010.04.003

Metheny, J., McWhirter, E. H., \& O'Neil, M. E. (2008). Measuring perceived teacher support and its influence on adolescent career development. J. Career Assess., 16, 218-237. doi: $10.1177 / 1069072707313198$

Mortimer, J. T., Zimmer-Gembeck, M. J., Holmes, M., \& Shanahan, M. J. (2002). The process of occupational decision making: Patterns during the transition to adulthood. Journal of Vocational Behavior, 61(3), 439. doi:10.1006/jvbe.2002.1885

Navarro, R. L., Flores, L. Y., \& Worthington, R. L. (2007). Mexican American middle school students' goal intentions in mathematics and science: A test of social cognitive career theory. J. Couns. Psychol., 54, 320-335. doi:10.1037/0022-0167.54.3.320

Parker, P. C., Perry, R. P., Hamm, J. M., Chipperfield, J. G., \& Hladkyj, S. (2016). Enhancing the academic success of competitive student athletes using a motivation treatment intervention 
INTERNATIONAL JOURNAL OF ACADEMIC RESEARCH IN BUSINESS AND SOCIAL SCIENCES Vol. 8, No. 9, Sept. 2018, E-ISSN: 2222-6990 @ 2018 HRMARS

(Attributional Retraining). Psychology of Sport and Exercise, 26, 113-122. doi:10.1016/j.psychsport.2016.06.008

Ramlee, M., \& Norhazizi, L. L. (2009). Gender imparity in technical and vocational education. Education for Diverse Learners. Serdang, Selangor: Universiti Putra Press.

Restubog, S. L. D., Florentino, A. R., \& Garcia, P. R. J. M. (2010). The mediating roles of career selfefficacy and career decidedness in the relationship between contextual support and persistence. J. Vocat. Behav., 77, 186-195. doi:10.1016/j.jvb.2010.06.005.

Ridpath, B. D. (2010). Perceptions of NCAA Division I athletes on motivations concerning theuse of specialized academic support services in the era of the Academic Progress Rate. Journal of Issues in Intercollegiate Athletics, 3, 253-271.

Savickas, M. (2002). Career construction: A developmental theory of vocational behavior. In D. Brown, \& Associates (Eds.), Career choice and development (pp. 149-205). San Francisco, CA: Jossey-Bass.

Sowa, C. \& Gressard, C. (1983). Athletic participation: Its relationship to student development. Journal of College Student Personnel, 24, 236-239.

Tang, M., Fouad, N. A., \& Smith, P. L. (1999). Asian Americans' career choices: A path model to examine factors influencing their career choices. J. Vocat. Behav., 54, 142-157. doi:10.1006/jvbe.1998.1651

Taylor, K. M., \& Betz, N. E. (1983). Applications of self-efficacy theory to the understanding and treatment of career indecision. Journal of Vocational Behavior, 22, 63-81. doi:10.1016/00018791(83)90006-4

Turner, S., \& Lapan, R. T. (2002). Career self-efficacy and perceptions of parent support in adolescent career development. Career Dev. Q., 51, 44-55. doi:10.1002/j.2161-0045.2002.tb00591.x.

Turner, S. L., Alliman-Brissett, A., Lapan, R. T., Udipi, S., \& Ergun, D. (2003). The career-related parent support scale. Measurement and Evaluation in Counseling and Development, 36(2), 83-94.

Van-Raalte, J. L., Cornelius, A. E., Brewer, B. W., Petitpas, A. J., \& Andrews, S. R. (2017). StudentAthlete Career Development. Springfield, MA: Springfield College Press.

Wang, S., Tomlinson, E. C., \& Noe, R. A. (2010). The role of mentor trust and protégé internal locus of control in formal mentoring relationships. Journal of Applied Psychology, 95, 358-367. doi:10.1037/a0017663 
INTERNATIONAL JOURNAL OF ACADEMIC RESEARCH IN BUSINESS AND SOCIAL SCIENCES

Vol. 8, No. 9, Sept. 2018, E-ISSN: 2222-6990 (C) 2018 HRMARS

Winston, R. B., Miller, T. K., \& Prince, J. S. (1982). Assessing student development. Athens, GA: Student Development Associates.

\section{Corresponding Author}

Elaiyaraj Retnam

Department of Professional Development and Continuing Education

Faculty of Educational Studies

Universiti Putra Malaysia, UPM, 43400 Serdang, Selangor, Malaysia

Email: elaiyaraj89@gmail.com 